\title{
STRONG MILITARY FAMILIES INTERVENTION ENHANCES PARENTING REFLECTIVITY AND REPRESENTATIONS IN FAMILIES WITH YOUNG CHILDREN
}

\author{
M.M. JULIAN, M. MUZIK, M. KEES, M. VALENSTEIN, AND K. L. ROSENBLUM \\ University of Michigan
}

ABSTRACT: Military families face many challenges due to deployment and parental separation, and this can be especially difficult for families with young children. The Strong Military Families (SMF) intervention is for military families with young children, and consists of two versions: the Multifamily Group, and a Home-based psychoeducational written materials program. The Multifamily Group was designed to enhance positive parenting through both educational components and in vivo feedback and support during separations and reunions between parents and children ( $n=78$ parents). In the present study, we examine parenting reflectivity and mental representations in mothers versus fathers in military families, service members versus civilian spouses/parenting partners, and before versus after participation in the SMF Multifamily Group and Home-based interventions. Parenting reflectivity and mental representations were coded from the Working Model of the Child Interview (WMCI; C.H. Zeanah \& D. Benoit, 1995). Results suggest that neither parenting reflectivity nor WMCI typology differs between mothers and fathers in military families, or between service members and civilian parenting partners. Furthermore, there was substantial stability in parenting reflectivity and WMCI typology from baseline to posttest, but participation in the Multifamily Group, relative to Home-based, was associated with improvements in both parenting reflectivity and WMCI ratings from baseline to postintervention.

Keywords: military families, parenting reflectivity, intervention

RESUMEN: Las familias militares enfrentan muchos retos debido a las distantes asignaciones de servicio y la separación de los padres, lo cual puede ser específicamente difícil para familias con niños pequeños. La intervención Familias Militares Fuertes (SMF) es para familias militares con niños pequeños y consta de dos versiones: un Grupo Múltiple de Familias y un programa sicoeducativo de materiales escritos con base en casa. El Grupo Múltiple de Familias se diseñó para mejorar la crianza positiva tanto a través de componentes educativos como de reacciones y apoyo en vivo durante las separaciones y reuniones entre padres y niños $(n=78$ padres). En el presente estudio, examinamos el poder de reflexión sobre la crianza y las representaciones mentales en mamás vs. papás en familias militares, miembros del servicio militar vs. cónyuges civiles/parejas conyugales en la crianza, y antes vs. después de la participación en el Grupo Múltiple de Familias SMF y en las intervenciones con base en casa. El poder de reflexión sobre la crianza y las representaciones mentales se codificaron usando el Modelo de Trabajo de la Entrevista del Niño -WMCI- (Zeanah y Benoit, 1995). Los resultados sugieren que ni el poder de reflexión ni la tipología del WMCI difieren entre mamás y papás en familias militares, o entre miembros del servicio militar y sus parejas conyugales civiles en la crianza. Es más, se dio una estabilidad de importancia en el poder de reflexión y la tipología WMCI entre el punto de referencia y la examinación posterior, pero la participación en el Grupo Múltiple de Familias, en relación con la intervención en casa, se asoció con mejoras tanto en el poder de reflexión como en los puntajes WMCI entre el punto de referencia y la intervención posterior.

Palabras claves: familias militares, poder de reflexión sobre la crianza, intervención

RÉSUMÉ: Les familles de militaires font face à de nombreux défis du fait des déploiements et de la séparation parentale, et cela peut s'avérer particulièrement difficile pour les familles avec de jeunes enfants. L'intervention Familles Militaires fortes (ici abrégé en français FMF, SMF en anglais, pour Strong Military Families) est destinée aux familles de militaires avec de jeunes enfants et consiste en deux versions: un Groupe Multifamilial, et

The research presented was supported through funds from the Ethel \& James Flinn Foundation (PI: K.L.R.), Eunice K. Schriver National Institute of Child Health and Human Development (5 R21 HD072375-02; PI: K.L.R.), and Welcome Back Veterans, an initiative of Major League Baseball and the McCormick Foundation (PI: Greden; Co-I: K.L.R.). We thank the community agencies (Easter Seals in Oakland County, Judson Center in Macomb County) and their clinicians serving the families for participating in this trial. We thank the families who participated in this project. We acknowledge the valuable efforts of the Strong Military Families and the University of Michigan Military Support Programs and Networks project staff in program development, implementation, and data collection. T32 postdoctoral fellowship funding (HD079350; PI: J. Lumeng) supported the primary author.

There are no disclosures of conflicts of interest.

Direct correspondence to: Katherine L. Rosenblum, Department of Psychiatry, University of Michigan, Ann Arbor, MI 48103; e-mail: katier@med.umich.edu. 
une intervention à domicile avec programme de matériel psychoéducatif écrit. Le Groupe Multifamilial a été conçu afin de mettre en valeur le parentage positif à travers des composantes éducatives et du feedback in vivo et du soutien durant les séparations et les réunions entre les parents et les enfants ( $n=78$ parents). Dans cette étude nous examinons la réflectivité de parentage et les représentations mentales chez les mères et les pères de familles de militaires, les membres du service comparés aux épouses civiles et aux partenaires de parentage civils, et avant par rapport à après la participation au Groupe Multifamilial FMF et les interventions à domicile. La réflectivité de parentage et les représentations mentales ont été codées à partir du Modèle de Travail de l'Entretien de l'Enfant (Zeanah \& Benoit, 1995). Les résultats suggèrent que ni la réflectivité de parentage ni le Modèle de Travail de l'Entretien de l'Enfant ne diffèrent entre les mères et les pères dans les familles militaires ou entre les membres du service et les partenaires de parentage civils. De plus il y avait une stabilité importante dans la réflectivité de parentage et la typologie du Modèle de Travail de l'Entretien de l'Enfant du niveau de référence jusqu'après le test, mais la participation au Groupe Multifamilial, par rapport à la participation à domicile, était liée à des améliorations dans à la fois la réflectivité de parentage et les scores du Modèle de Travail de l'Entretien de l'Enfant du niveau de référence à après l'intervention.

Mots clés: familles militaires, réflectivité de parentage, intervention

ZUSAMMENFASSUNG: Militärische Familien stehen durch den Einsatz und die Trennung der Eltern vor vielen Herausforderungen, was besonders für Familien mit Kleinkindern schwierig sein kann. Die Intervention „Strong Military Families“ (SMF) richtet sich an Militärfamilien mit Kleinkindern und besteht aus zwei Versionen: Aus einer Mehrfamiliengruppe und einem psychoedukativen schriftlichen Materialprogramm für Zuhause. Die Mehrfamiliengruppe wurde entwickelt, um die positive Elternschaft sowohl durch pädagogische Komponenten als auch durch in vivo Feedback und Unterstützung bei Trennungen und Wiedervereinigungen zwischen Eltern und Kindern $(n=78$ Eltern) zu fördern. In der vorliegenden Studie untersuchen wir die Reflektivität und mentalen Repräsentationen von Eltern bei Müttern vs. Vätern in militärischen Familien, Dienstmitgliedern vs. zivilen Ehepartnern/Erziehungspartnern und vor vs. nach der Teilnahme an der SMF Mehrfamiliengruppe und psychoedukativen Intervention Zuhause. Die elterliche Reflektivität und mentalen Repräsentationen wurden aus dem "Working Model of the Child Interview" (WMCI; Zeanah \& Benoit, 1995) kodiert. Die Ergebnisse deuten darauf hin, dass sich weder die elterliche Reflektivität noch die Typologie der WMCI zwischen Müttern und Vätern in Militärfamilien oder zwischen Dienstmitgliedern und zivilen Ehepartnern unterscheiden. Außerdem gab es eine beträchtliche Stabilität in der elterlichen Reflektivität und WMCI-Typologie vom Beginn der Untersuchungen bis zum Post-Test, aber die Teilnahme an der Mehrfamiliengruppe, im Vergleich zur psychoedukativen Intervention Zuhause, war mit Verbesserungen sowohl in der elterlichen Reflektivität als auch in der WMCI-Bewertung vom Untersuchungsbeginn zur Post-Intervention verbunden.

Stichwörter: Militärfamilien, elterliche Reflektivität, Intervention

抄録: 軍人家族は配属や親との分離のために多くの困難に直面する。そしてこれは幼い子どものいる家族には特に困難になり得る。強 い軍人家族The Strong Military Families (SMF)介入は、幼い子どものいる軍人家族のためのもので、2つの型がある。それらは、複数家族 グループと資料を用いて家庭で行う心理教育的プログラムである。複数家族グループは、教育的な要素および親子の分離と再会のそ の場でのフィードバックと支援の両者を通して、ポジティブな育児を増強するようにデザインされた(n=78人の親)。この研究では、 私たちは、軍人家族の母親対父親、軍人対民間人の配偶者/養育パートナー、そしてSMF複数家族グループと家庭での介入に参加前対 参加後において、育児の内省性と心的表象を調査した。育児の内省性と心的表象は、 the Working Model of the Child Interview (Zeanah \& Benoit, 1995) によってコード化された。結果から、軍人家族の母親と父親、あるいは軍人と民間人の養育パートナーの間に、育児の内 省性あるいはWMCIタイプについて違いは示されなかった。さらに、基準線からテスト後にかけて、育児の内省性およびWMCIタイプ にかなりの安定性があったが、家庭におけるプログラムに比べて、複数家族グループに参加することは、育児の内省性およびWMCI評 価の両者の基準線から介入後への改善と関連していた。

キーワード：軍人家族, 育児の内省性, 介入

摘要：由於軍事部署和父母在不同地方居住, 軍人家庭面臨許多挑戰, 這些挑戰對於有小孩的家庭尤其嚴重。強大軍人家庭干預 (SMF) 是 為有小孩的軍人家庭進行的干預, 包括兩個版本: 一個多家庭小組和一個家庭式的心理教育書面材料計劃。多家庭小組旨在通過教育、反饋 和支持, 在父母與子女 (78名父母) 的分離和團聚期間, 加強積極的父母教養。在本研究中, 我們考察在軍人家庭、服務人員與平民配偶/養育 夥伴的父母, 以及參與 SMF 多家庭小組和家庭式干預前後的父母反思和心理表徵。我們以兒童訪談的工作模式 (Zeanah\&Benoit, 1995), 編 碼父母反思能力和心理表徵。結果表明, 在軍人家庭父母之間, 或服務人員和平民養育夥伴之間, 父母反思能力和WMCI類型學並無不同。 此外, 從基線到測試後, 父母反思能力和WMCI類型相當穩定, 但和家庭式干預相比, 多家庭小組的參與, 與從基線到干預後的父母反思能力 和WMCI評分之改善相關。

關鍵詞: 軍人家庭, 養育反思, 干預 


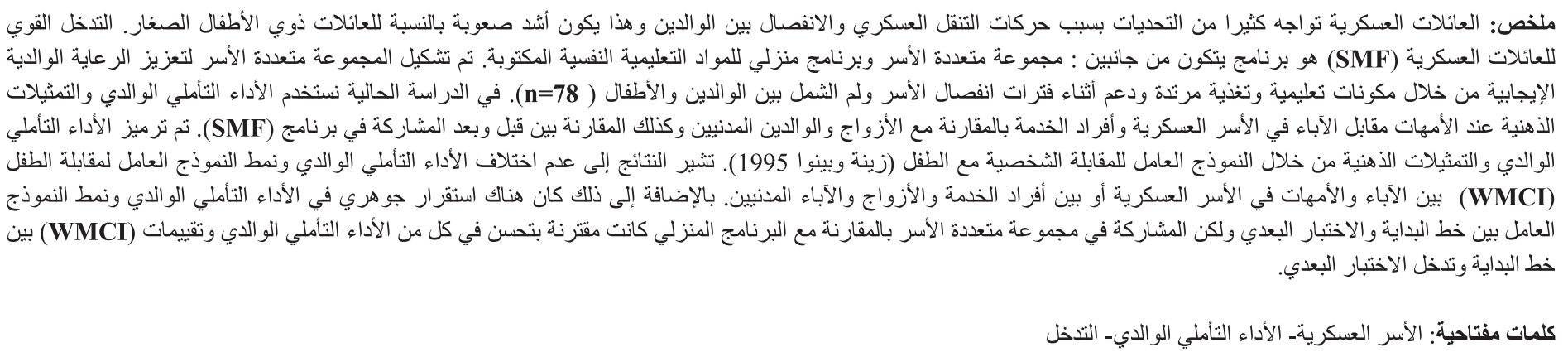

Since 2001, roughly 2.7 million American troops have been deployed to Iraq or Afghanistan, and $48 \%$ of these service members have a child under 6 years of age (U.S. Department of Defense, 2015). Military families display remarkable resilience despite the many challenges they face, and yet the normative stresses associated with managing parenting roles across the deployment cycle can lead many families to struggle (Dayton, Walsh, Muzik, Erwin, \& Rosenblum, 2006; Lincoln, Swift, \& Shorteno-Fraser, 2008). When one parent deploys, the nondeployed parent is more likely to report high levels of parenting stress, mood symptoms, and adjustment difficulties (Bender, 2008). Reunification also poses challenges, including reestablishing relationships, roles, and routines as well as potentially necessary accommodation to injuries or psychological impacts. Throughout this process, children in military families must adjust as well; in particular, it can be challenging for military children to reconnect to a parent after separation, especially when the separation constituted a significant portion of their lives.

The current study sought to evaluate a multifamily group parenting intervention designed specifically for military families with young children; we examined the impact of the intervention on parents' attachment relationships with their children, assessed via key indicators of attachment security, parent mental representations of their children, and parenting reflectivity before and following participation in the Strong Military Families program.

\section{PSYCHOLOGICAL IMPACT OF MILITARY SERVICE ON PARENTS}

Service members who have deployed have elevated rates of posttraumatic stress disorder (PTSD), with studies reporting 4 to $17 \%$ prevalence rates for U.S. Iraq War veterans (Richardson, Frueh, \& Acierno, 2010), but substantially more may suffer from subclinical symptoms. For example, while most participants in a small study of military fathers who participated in a parenting support intervention did not meet cutoff criteria for a probable diagnosis of PTSD on a standard self-report checklist, nearly half had subclinical, but elevated, levels of trauma symptoms (Dayton et al., 2006). Over half of spouses of service members report negative emotional reactions (anxiety, loneliness, sadness, worry) related to their partner's deployment separation (Wexler \& McGrath, 1991). Army wives with a deployed spouse, relative to those with a spouse who was not deployed, also have higher rates of mental health diagnoses, with higher risk among those whose spouse deployed for over 11 months. The most commonly reported diagnoses for Army wives with a deployed spouse were depressive disorders (18-24\% higher than wives with nondeployed spouses), sleep disorders (21-40\% higher), anxiety disorders (25-29\% higher), and acute stress reaction and adjustment disorders (23-39\% higher; Mansfield et al., 2010).

\section{MENTAL HEALTH OF CHILDREN IN MILITARY FAMILIES}

While elevated rates of distress among parents in military families are a concern in their own right, parental distress also has implications for their children's mental health (Chu \& Lieberman, 2010). Young children in military families are at particular risk because they rely heavily on their parents to help them regulate their emotions and behaviors, but their parents are likely to be less available to them due to parental deployment and/or heightened stress. In fact, 4- to 17-year-old children of a deployed parent have higher levels of depression and more stressors than do children whose parents were not deployed, with younger children more vulnerable to problems related to parental deployment (Jensen, Martin, \& Watanabe, 1996). Among children aged 3 to 8 years, parental deployment was associated with an 18 to $19 \%$ increase in behavioral and stress disorders, and an $11 \%$ increase in outpatient psychiatric or behavioral care visits (Gorman, Eide, \& Hisle-Gorman, 2010). Furthermore, nearly one third of children under age 4 years had difficulty in their parent-child relationship upon reunion with the deployed parent (Barker \& Berry, 2009). While it is clear that young children in military families are at particular risk for difficulty relating to parental deployment and reintegration, empirical data in this area are limited, and researchers have called for further studies to assess attachment behaviors of this population in greater depth (Maholmes, 2012).

\section{ATTACHMENT, PARENTING REFLECTIVITY, AND MENTAL REPRESENTATIONS}

Caregiver-child relationships are known to be fundamental to young children's development; caregivers scaffold children's 
cognitive, physical, and socioemotional development and serve as a comforting support in times of distress. Attachment theory posits that internal working models, or mental representations of relationships, are foundational to attachment relationships (Bowlby, 1969). A parent's own experiences in relationships, including any history of maltreatment or trauma, can affect the interpretations and attributions they make in a relationship with their own child. Maternal representations begin to develop while the child is in utero, and are based in part on a mother's attributions and fantasies about the infant (Zeanah, Keener, \& Anders, 1986). A parent's subjective experience of his or her child shapes behavioral responses to the child, which in turn will shape the way the child behaves with the parent. A parent's ability to reflect on the infant's internal state and motivations ("parenting reflectivity") is related to parental behavioral sensitivity (Rosenblum, McDonough, Sameroff, \& Muzik, 2008) and the child's attachment security (Zeanah, Benoit, Hirshberg, Barton, \& Regan, 1994). Parental representations are often assessed through the Working Model of the Child Interview (WMCI; Zeanah \& Benoit, 1995), which is a semistructured interview that elicits parents' perception of their baby and their relationship. These interviews can be coded to classify parents' representations of their babies as "balanced" (rich descriptions of the baby, and a sense that the parent values their relationship with the infant), "disengaged" (limited emotional involvement with the infant), or "distorted" (inconsistent descriptions of the infant, self-involved, or insensitive to the infant), reflecting qualities that relate to the security of infants' attachment relationships (Zeanah \& Benoit, 1995). Parents with secure, or balanced patterns of representation are better able to access and process emotional experience without minimization or distortion, which is thought to play a role in the child's development of emotion regulation capacities (Rosenblum, Dayton, \& McDonough, 2006). Importantly, parental representations are modifiable in reaction to later relationship experiences or interventions (Bretherton \& Munholland, 2008); thus, parental representations can be a key target of work with parents of young children.

Particularly in the context of stress and trauma, attachment relationships are central to a young child's healthy development. For securely attached children, the presence of an attachment figure plays a role in modulating a child's physiological and behavioral responses to stressors (Gunnar \& Quevedo, 2007). But when children lack a secure attachment relationship, they are less able to regulate their stress responses and, correspondingly, are more likely to have disturbances in their hypothalamic-pituitary-adrenal axis activity and later behavioral and emotional problems (Gunnar \& Quevedo, 2007; Hertsgaard, Gunnar, Erickson, \& Nachmias, 1995; van IJzendoorn, Schuengel, \& Bakermans-Kranenburg, 1999). A secure attachment relationship is more likely to emerge when parents are not overburdened by their own stresses and are emotionally available to coregulate their young child. Thus, in stressful circumstances such as the deployment of a parent, a secure attachment relationship is likely to buffer a child's stress response and diminish the chances of stressful experiences having a negative effect on the child's well-being. The centrality of parental representations to the development of an attachment relationship suggests that parental representations may provide a window into the security of the parent-child attachment relationship as well as a meaningful target of intervention.

The vast majority of research thus far on parenting reflectivity and mental representations has taken place with mothers, and the generalizability of these ideas to fathers is not yet clear. Beginning research has suggested that mothers may have better reflective functioning than do fathers (Esbjørn et al., 2013), and fathers' attachment representation predicts the quality of fatherchild relationships and child outcomes (Slade, 2005). However, one study found no relation between reflective functioning and self-reported parenting behaviors in a sample of fathers (Stover \& Kiselica, 2014). More research is needed to clarify how parenting reflectivity and mental representations function for fathers versus mothers of young children.

\section{PARENTING IN MILITARY FAMILIES}

Military parents endorse a high level of stress related to parenting, and they are specifically concerned about managing separations and reunions with their families, reconnecting with their children after deployment, adapting their expectations from military life to family life, and coparenting (Walsh et al., 2014). A deployed parent's adjustment is often made more complicated when he or she has a very young child because the child may be in a very different developmental stage when he or she returns. The parent-child relationship needs to be reestablished with a young child who may have more difficulty holding onto the memory of a parent through deployment. Further, the child may now require a different set of parenting skills than before deployment, due to the progression of development over time.

A service member's immersion in military culture can impact his or her experience of parenting. Military culture is driven by routine, but parents of young children must adjust to a lifestyle at home that is full of unpredictability and requires considerable flexibility (Walsh et al., 2014). The emotionally taxing and stressful nature of combat understandably leads many service members to maintain emotional distance from their loved ones to protect themselves from further loss. In fact, avoidance-numbing PTSD symptoms have been found to significantly interfere with parenting for military parents with older children (Ruscio, Weathers, King, \& King, 2002). Parents' hyperarousal and hypervigilance, on the other hand, is thought to lead to parenting that is more intensely reactive than the child's behavior demands (Lieberman, 2004). Adjustment back to home life and day-to-day parenting often involves co-managing their children's emotions. Many service members have reported difficulty helping their children regulate their emotions, and note that their children's negative emotions can trigger difficult memories from their military and combat experiences (Dayton et al., 2006). Military parents have reported that they have difficulty reestablishing connections with their younger children upon reunification, nurturing and being emotionally available to their children, and managing their child's emotions (and 
staying calm themselves) when their child is upset (Walsh et al., 2014).

\section{PARENTING REFLECTIVITY IN MILITARY FAMILIES}

Military parents' experiences with separation through deployment as well as traumatic experiences during deployment or their own childhood are bound to have an effect on their interpretations and attributions in their relationship with their young children. Military parents also may be conflicted between the emotionally laden work of parenting and the culture of emotional distance more typical of the military. While parenting reflectivity has been hypothesized to be a key process in parent-child relationships and an important target for intervention in military families (Paris, DeVoe, Ross, \& Acker, 2010), it has not yet been studied in military parents of young children, and we do not know how mothers versus fathers in military families compare on their parenting reflectivity. Researchers have called for more research to address attachment behaviors in military families with young children so that we can better understand the nuances of how military service affects young children's development in the context of their relationship with their parents (Maholmes, 2012). As discussed earlier, both military service members and their spouses are at elevated risk of various forms of psychopathology (Mansfield et al., 2010; Richardson et al., 2010), likely due in large part to the stress of deployment. It has been posited that a primary way in which parental psychopathology affects young children is through the parents' reflective capacity (Slade, 2005). Various forms of psychopathology are associated with deficits in the ability to understand another person's subjective experience (Slade, 2005), and this can lead individuals to respond to others in insensitive ways. Because parental reflective capacity is closely linked to a young child's experience with his or her parent, this can be a critical variable to assess and a meaningful target of intervention.

Specifically, it will be important to know how parenting reflectivity and children's attachment behaviors are affected in the context of mother-child versus father-child relationships, and service member-child versus spouse-child relationships. Furthermore, parenting reflectivity is known to be stable over time, with $71 \%$ (Theran, Levendosky, Bogat, \& Huth-Bocks, 2005) to $76 \%$ (Borghini et al., 2006) of mothers falling into the same attachment category on the WMCI over the course of 1 year. However, it is not yet known whether the same level of stability is seen among military parents of young children. Understanding how parenting reflectivity works in these populations will provide information that is critical to better targeting military family interventions in the future.

\section{INTERVENTIONS FOR MILITARY FAMILIES}

Given the unique stresses associated with military family life, several existing preventive intervention approaches have aimed to support military families with children (Gewirtz, Pinna, Hanson, \& Brockberg, 2014; Lester et al., 2011), although only a small num- ber have included very young children ( $\leq 5$ years). For example, Families OverComing Under Stress (FOCUS) is a widely implemented resilience-enhancing program for military families with children ages 3 to 17 (Children ages 6 years and up participate more fully.) FOCUS consists of eight sessions, divided between parent sessions, child sessions, and family sessions (Lester et al., 2011), and aims to help military families to develop a shared narrative about the experience of deployment and other stressors, and provides psychoeducation about deployment and coping strategies. Results of a quasi-experimental pre/post design study have suggested that completion of FOCUS is associated with significant improvements in distress level for service members, civilian parents, and their children (Lester et al., 2016; Lester et al., 2012; Saltzman, Lester, Milburn, Woodward, \& Stein, 2016). Studies of FOCUS have yielded promising data, but it is not specifically focused on addressing the struggles faced by military families with young children. Another emerging intervention for military families is After Deployment, Adaptive Parenting Tools (ADAPT; Gewirtz et al., 2014). ADAPT is a 14-week group-based, Webenhanced parenting training program that is adapted from the Parent Management Training Oregon Model (Forgatch \& DeGarmo, 1999) and targeted at military families with at least one child between ages 4 and 12 years. A randomized controlled trial suggests that parents who participate in ADAPT demonstrate improved parenting behavior, locus of control and emotion regulation, and reduced psychological distress and suicidal ideation; children who participate in ADAPT also have better adjustment (Gewirtz, DeGarmo, \& Zamir, 2016, 2017; Piehler, Ausherbauer, Gewirtz, \& Gliske, 2016).

An additional promising approach was developed specifically with young children in mind, Strong Families Strong Forces (SFSF; DeVoe, Ross, \& Paris, 2012). SFSF is delivered to individual families by a trained clinician in the family home. A randomized controlled trial demonstrated that SFSF is associated with improvements in reflective capacity, reductions in parenting stress and mental health distress, and greater perceived self-efficacy for those with more post-traumatic stress symptoms (DeVoe, Paris, Emmert-Aronson, Ross, \& Acker, 2017). Similarly, Baby Boot Camp (Schachman, Lee, \& Lederma, 2004) targets military wives who are pregnant for the first time, and provides a 4-week childbirth and parenting preparation program based on a resilience paradigm and infused with information and resources specific to military families. In a randomized clinical trial comparing this approach to a traditional childbirth education program, Baby Boot Camp participants showed an increase in internal and external resources immediately after the intervention, but effects faded to nonsignificant at 6 weeks' postpartum (Schachman et al., 2004). Other approaches, such as Filial Therapy (Chawla \& Solinas-Saunders, 2011), have been proposed as interventions that would be fitting for military families with young children, but have not yet been rigorously studied in this population.

Taken together, these studies have suggested that military families can benefit from preventive intervention programs to promote resilience. Yet, prior studies are often limited by the absence 
of a no-treatment comparison group of military families (Lester et al., 2016; Lester et al., 2016), the absence of an explicit focus on infancy and early childhood, an emphasis on work with a single family (vs. connecting families with one another), and/or lack of attention to outcomes of particular relevance to infants and young children, such as indices of parent-child attachment security. The current study aims to fill a gap by examining the efficacy of a brief, multifamily preventive intervention for military families with young children, the Strong Military Families Program (SMF), for promoting a key indicator of early attachment security, that is, parenting reflectivity and the security of parents' mental representations of their children.

\section{THE CURRENT STUDY}

SMF, the focus of this study, is an intervention to enhance positive parenting in military families with young children (for a description of the intervention, see Rosenblum et al., 2015). There are two versions of SMF: a home-based psychoeducational materials program (Home-based), and a multifamily therapeutic group (Multifamily Group). It is adapted from an existing civilian parenting program (Mom Power; described in Muzik et al., 2015), and the Multifamily Group integrates: (a) parent education with specific attention to the experiences of military families with young children, (b) opportunities for supported parent-child interaction to enhance positive parenting, (c) introduction to self-care and stress-reduction techniques to reduce mental health symptoms, (d) a group context to increase social support, and (e) individualized referrals to enhance connection to resources. SMF is rooted in attachment theory and trauma theory, and aims to help parents to make more positive and balanced attributions toward their children, engage in more sensitive and nurturing parenting, and learn effective self-care strategies. The intervention takes place over 10 to 12 weeks, and consists of 10 group sessions and one to three individual sessions with facilitators. During the group sessions, parents meet together with the facilitators while their children participate in a child group focused on child-led play. This format allows for facilitators to support parent-child interactions around separations and reunions since parents and children separate for the group. The SMF Multifamily Group also aims to increase participants' social connectedness through the group format, increase parents' ability to manage stress and regulate their emotions, and provide a "warm hand off" to additional services that each family may need. The SMF Home-based program utilizes psychoeducational materials that are parallel to the information provided in the Multifamily Group, but it lacks an in-person component.

Thus, the SMF Multifamily Group intervention addresses struggles that often occur in military families with young children through both educational components and in vivo feedback and support during separations and reunions between parents and children. Both the psychoeducational material about attachment and supported parent-child interaction during separations and reunions function to help parents shift their understanding of their children's behaviors, with the goal of helping parents to reach more balanced representations of their children, thus providing more sensitive and responsive care to them. All families in this group have experienced deployments, so separations and reunions are often challenging and may trigger feelings related to past or future deployments. Ultimately, it is hypothesized that this intervention will provide tools to help parents of young children to better meet their young children's needs in the context of the many stresses faced by military families. The current study sought to test the primary hypothesis that the SMF Multifamily Group intervention is associated with improvements in parents' representations of their children, and in their reflective capacity.

\section{STUDY HYPOTHESES}

This study will explore how parenting reflectivity may differ among mothers versus fathers in military families, and between service members versus civilian spouses/parenting partners. Because this question has not previously been examined in the literature, these analyses will be exploratory.

In addition, we hypothesized that parents' mental representations, as indexed both by WMCI Typology classification and Parenting Reflectivity scale scores, would change as a function of participation in the SMF Multifamily Group. We expected rates of Balanced representations and scores on Parenting Reflectivity to increase from pre- to postgroup only for those who participated in the Multifamily Group condition.

\section{METHOD}

This study was approved by the University of Michigan Institutional Review Board (Protocol No. HUM00062935), and written informed consent was obtained from all adults. Each parent was compensated up to $\$ 90$ for participation in study assessments, and both treatment and comparison groups were compensated equally.

The current study involved a quasi-experimental design, with parents enrolled for immediate participation in a Multifamily Group or in a wait-list Home-based condition that involved receipt of written materials sent to their home as an attention-control comparison group $(n=107)$. Participants were geographically dispersed across the state; those who were able to attend a group offered in their community "in-person" were enrolled in the Multifamily Group. Those who were unable to attend those groups but had interest in the program were eligible for our wait-list Home-based condition, during which time they received written materials covering the content of the curriculum provided in the Multifamily Group; after completing this Home-based condition, these participants were eligible to participate in a subsequent group when one that was accessible to them became available. Participants who did not complete baseline $(n=3)$ or postintervention ( $n=3$ ) WMCIs, parents who withdrew from the study prior to the intervention $(n=13)$, and parents who dropped out of the study before completion of the intervention and/or did not complete follow-up assessments $(n=10$, all from the Home-based condition) were excluded from this report. Analyses 
reported here reflect contrasts only between parents who initially participated in the Multifamily Group $(n=33)$ versus those who initially participated in the wait-list comparison condition (i.e., Home-based; $n=45$ ). Participants who were included in $(n=78)$ versus excluded from analyses $(n=29)$ did not differ significantly on parent or child age or gender, marital status, singleparent status, income, parent education, military status, number of children in the household, or ethnicity. However, employed participants were marginally more likely to be included in the sample, $t(39.39)=-1.82, p=.08$, and Hispanic or Latino(a) participants were significantly more likely to be included in the sample, $t(65)=-2.99, p<.01$. Eight Multifamily Groups were conducted over the study period in varying geographic regions across the state.

Parents $(n=78)$ were recruited to participate via flyers, contacts at community events, and referrals from agencies serving military families. Eligible parents were either a service member/veteran with history of deployment and/or his or her spouse with at least one child $\leq 7$ years old. Both parents were eligible to participate, together or separately. Parent caregivers who participated were mothers $(n=46)$, fathers $(n=29)$, and grandparents who cared for their grandchildren during deployments $(n=3)$, all referred to as parents. About half of the parents who participated in this program were military service members.

The majority of parents were between 22 to 40 years old $(84.6 \%)$, and were married, engaged, or living with their partner $(89.8 \%)$. Most parents were Caucasian (78.2\%) and had some college education $(47.4 \%)$ or a 4 -year college $(30.8 \%)$ or graduate $(10.3 \%)$ degree. A minority of participants $(10.3 \%)$ identified as Hispanic or Latino(a). Most parents were employed (70.5\%), with a family income of at least $\$ 50,000$ per year $(53.9 \%)$. Most households had $1(33.3 \%)$ or $2(35.9 \%)$ children. The sample of parents who participated included those from families with one parent who had a personal military service connection, either as a current service member or a veteran $(33.3 \%)$; those from dual military service career couple families $(19.2 \%)$; and civilian parenting partners $(35 \%)$. Of the 41 parents with a personal service connection, approximately one fourth $(n=12)$ were women. Consistent with the geographic region, the majority of the sample served in the Reserve Component (National Guard and Reserves); about half of the sample experienced one deployment whereas the other half had two or more deployments.

Parents were asked to complete questionnaires in reference to their oldest child within the age range; children ranged from 1 to $7(M=4$ years, $S D=1.60)$, and $79.5 \%$ were $\leq 5$ years old; half were male.

\section{Assessments}

Data were collected at home visits conducted prior to family involvement in either the SMF Multifamily Group or the Homebased condition, and again 2 months following group completion. Parent questionnaires assessed parent demographics and service history. Parent interviews were conducted using the widely validated WMCI.

\section{Measures}

Demographic Questionnaire.. Parents responded to a series of questions about household composition, deployment history, and resources.

WMCI (Zeanah \& Benoit, 1995). This semistructured narrativebased interview is designed to assess parents' mental representations of parenting and of their young children. The interview lasts approximately 45 to $60 \mathrm{~min}$ and includes a series of open-ended questions. Interview responses are audio-recorded and transcribed, and both the content and narrative features of the WMCI are coded from the transcription to assess the overall security of the representation (the "Typology" classification) as well as a Parenting Reflectivity scale. A number of prior studies have confirmed the reliability and validity of the WMCI, including associations with both parenting and child outcomes (Leung, Miller, Lumeng, Kaciroti, \& Rosenblum, 2015; Rosenblum et al., 2006; Vreeswijk, Maas, \& van Bakel, 2012). Sample questions and descriptions of the coding system are available in prior publications (Leung et al., 2015); coding relevant to the current analyses is described briefly here.

WMCI typology classifications. The WMCI can be used to derive three main typology classifications: the Balanced, Disengaged, and Distorted categories. Balanced representations are those in which the parent is able to describe their child and their relationship with their child in an open, coherent, well-organized manner. Parents with Balanced representations are generally accepting of their children, and while they may describe challenges or concerns, these are not overwhelming. Parents in this category convey a level of psychological involvement and are able to share memories and examples to illustrate their general descriptions of their child. In contrast, parents with Disengaged representations tend to convey some degree of emotional distance; this may manifest as either a paucity of memory or detail about the child or as a cool and distancing derogation of the child (e.g., sarcasm about the child). Parents in this category often tend to have very brief narratives as they either deny memories or provide simple, unelaborated, and often contradicted information (e.g., describing the child as "great," but then providing examples that reveal parents' frustration with the child's challenging behavior, and failing to acknowledge or integrate these two disparate experiences). In prior work, this category has been described as one that reflects an unconscious "emotionminimizing" approach. Finally, the parents with Distorted representations often provide narratives that are low in coherence with an associated "emotion-activating" style. Narratives provided by parents in this category may be confusing and hard to follow as the parent provides voluminous information, but fails to integrate it for the listener. These narratives commonly also include themes suggesting role reversal, parental self-focus, or distraction with other concerns preoccupying the parent. In prior research, these three 
typology categories have been validated across a wide range of parent and child outcomes, and have distinguished clinical from nonclinical samples (Vreeswijk et al., 2012). Balanced typologies are most commonly associated with child attachment security; nonbalanced (disengaged and distorted) representation typologies have been associated with child avoidant and ambivalent-resistant attachment classifications (Rosenblum et al., 2006; Vreeswijk et al., 2012). Consistent with prior work demonstrating interrater reliability for the WMCI, for the present study two independent coders, blind to pre- versus post-intervention status, were trained to code the WMCI and separately coded $20 \mathrm{WMCI}$ transcripts, with $80 \%$ agreement on main classification type. Disagreements on these 20 WMCI transcripts were resolved through discussion, and consensus codes were used.

WMCI Parenting Reflectivity. The WMCI Parenting Reflectivity Scale is a 5-point scale ( $1=$ Extremely Limited, $2=$ Limited, 3 = Moderate, $4=$ High, $5=$ Very High) developed to assess the parent's capacity, as evidenced in his or her responses to the WMCI interview, to take the child's perspective and to acknowledge that mental states (including thoughts, feelings, desires, perceptions) underlie and motivate both their own and their child's behavior. This scale was developed based on the work identifying parent Reflective Functioning as a critical predictor of child attachment security (Fonagy, Steele, Steele, Moran, \& Higgit, 1991). The WMCI Parenting Reflectivity scale has been demonstrated to predict parent behavioral sensitivity and mind-minded comments during child-parent interaction, and to have sensitivity to change from pre to post a parenting intervention (Muzik et al., 2015; Rosenblum et al., 2008). Consistent with prior work demonstrating interrater reliability for the Parenting Reflectivity scale, for the present study two independent WMCI coders, blind to pre- versus post-intervention status, were trained to code the Parenting Reflectivity scale, and on a set of 20 WMCI transcripts separately coded, demonstrated strong interrater reliability $(\mathrm{ICC}=.85)$. On this subset of double-coded transcripts, consensus codes were used in the case of disagreements between raters. Because it was thought that movement from a limited reflective score to an adequate or high reflective score (e.g., 2 to 3 ) might be more meaningful than was a move on the extremes of the scale (e.g., 1 to 2, 4 to 5), Parenting Reflectivity scores were dichotomized into "less reflective" and "more reflective" groups (1-2 vs. 3-5) for some analyses.

\section{RESULTS}

\section{Preliminary Analyses}

At baseline, intervention conditions (Multifamily Group, Homebased) did not differ from each other on WMCI typology (Balanced, Disengaged, Distorted), $\chi^{2}(2, n=78)=2.142, p=.34$. When WMCI typology was dichotomized into secure (Balanced) versus insecure (Disengaged, Distorted), SMF groups also did not differ significantly from one another, $\chi^{2}(1, n=78)=2.13, p=.15$ (see Table 1). At baseline, Multifamily Group participants $(M=$ $3.06, S D=1.03$ ) had marginally higher ratings on Reflective Par-
TABLE 1. Working Model of the Child Interview Typology Classifications Before and After the Strong Military Families Intervention in Home-based and Multifamily Group Formats

\begin{tabular}{lccccc}
\hline & \multicolumn{2}{c}{ Home-Based $(n=45)$} & & \multicolumn{2}{c}{ Multifamily Group $(n=33)$} \\
\cline { 2 - 3 } \cline { 5 - 6 } & Baseline & Post & & Baseline & Post \\
\hline Balanced & 24 & 21 & & 23 & 24 \\
Disengaged & 10 & 17 & & 5 & 7 \\
Distorted & 11 & 7 & & 5 & 2 \\
\hline
\end{tabular}

enting than did Home-based participants $(M=2.60, S D=1.14)$, $t(76)=-1.84, p=.07$.

Across groups, baseline Parenting Reflectivity was strongly correlated with postintervention Parenting Reflectivity, $r(78)=0.48, p<.01$. The association between baseline and postintervention WMCI typology (Balanced, Disengaged, Distorted) across intervention groups also was significant, $\chi^{2}(4, n=78)=$ $13.88, p<.01$. Both Parenting Reflectivity and WMCI typology are generally stable over time in this sample; when both variables are dichotomized, $71.7 \%$ (parenting reflectivity) and 69.2\% (WMCI) of the sample maintained the same classification at baseline and postintervention.

Multifamily Group and Home-based participants did not differ on parent or child age, parent or child gender, marital status, single-parent status, family income, education, employment status, military status, or number of children in the family, but the Multifamily Group had marginally more non-Hispanic/Latino(a) parents than did the Home-based group, $\chi^{2}(1, n=66)=2.76, p=$ .10. At baseline, Hispanic/Latino(a) participants were significantly more likely to have insecure WMCI classifications, $\chi^{2}(1, n=66)$ $=3.95, p=.05$. While parental education was marginally associated with WMCI classifications, $\chi^{2}(3, n=78)=6.33, p=.10$, the association did not follow a systematic pattern. WMCI classifications were not related to any other demographic characteristics at baseline.

\section{Main Analyses}

Parenting reflectivity. Parenting reflectivity (Less Reflective, More Reflective) did not differ based on military status (Military Service Member, Spouse/Other) at baseline, $\chi^{2}(1, n=78)=.21, p=$ .65 , or postintervention, $\chi^{2}(1, n=78)=1.79, p=.18$. Parenting reflectivity also did not differ between mothers and fathers at baseline, $\chi^{2}(1, n=78)=1.21, p=.27$, or postintervention, $\chi^{2}$ $(1, n=78)=.63, p=.43$.

Multifamily Group and Home-based participants differed from one another in parenting reflectivity at baseline, so analyses focused on change from baseline to postintervention rather than on absolute scores. Thus, baseline parenting reflectivity was entered in Step 1 of the regression analysis and intervention condition in Step 2, with these variables predicting postintervention parenting reflectivity. Intervention condition explained a significant amount of variance over and above baseline parenting reflectivity, $\beta=.28$, 
Baseline

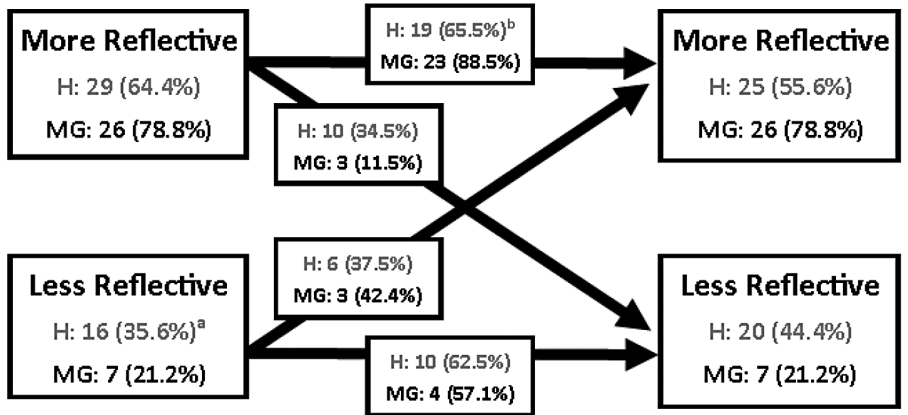

FIGURE 1. Parenting reflectivity at baseline and postintervention for Home-based (H) and Multifamily Group (MG) participants.

Note: $\mathrm{H}=$ Home-based, $\mathrm{MG}=$ Multifamily Group

${ }^{1}$ Percentages reflect percent of participants within a condition (Home-based, Multifamily Group) and timepoint classified in a given category

${ }^{2}$ Percentages reflect percent of participants within a condition and security rating (e.g., Home-based parents with a Less Reflective rating).

$t=2.85, p<.01$, suggesting that the incremental improvement in parenting reflectivity through this intervention was significantly greater among Multifamily Group participants than among Homebased participants.

When parenting reflectivity was dichotomized, a chi-squared test indicated that there was a significant association between baseline and postintervention parenting reflectivity for Multifamily Group participants, $\chi^{2}(1, n=33)=6.86, \mathbf{p}<.01$, and a marginal association for Home-based participants, $\chi^{2}(1, n=45)=3.28$, $p=.07$. The overall chi-squared test (Condition $\times$ Baseline Parenting Reflectivity $\times$ Postintervention Parenting Reflectivity) also was significant, $\chi^{2}(1, n=78)=9.93, p<.01$. As shown in Figure 1, more reflective parents were more likely to remain in the More Reflective category regardless of intervention condition, but this tendency was more pronounced for parents in the Multifamily Group (88.5\%) relative to the Home-based condition (65.5\%). Furthermore, slightly more Multifamily Group participants changed from Less Reflective to More Reflective categories (42.4\% of those who were Less Reflective at baseline) relative to the Home-based participants (37.5\% of those who were less reflective at baseline), and three times more Home-based participants changed from More Reflective to Less Reflective categories (34.5\% of those who were More Reflective at baseline) relative to the Multifamily Group participants $(11.5 \%$ of those who were More Reflective at baseline).

WMCI ratings. WMCI ratings (Secure, Insecure) did not differ based on military status (Military Service Member, Spouse/Other) at baseline, $\chi^{2}(1, n=78)=1.13, p=.29$, or postintervention, $\chi^{2}(1, n=78)=.58, p=.45$. WMCI ratings also did not differ between mothers and fathers at baseline, $\chi^{2}(1, n=78)=.00, p=$ .97 , or postintervention, $\chi^{2}(1, n=78)=.38, p=.54$.

WMCI ratings, dichotomized into Secure (Balanced) and Insecure (Disengaged, Distorted) categories, showed that there is a marginal association between baseline WMCI ratings and
Baseline

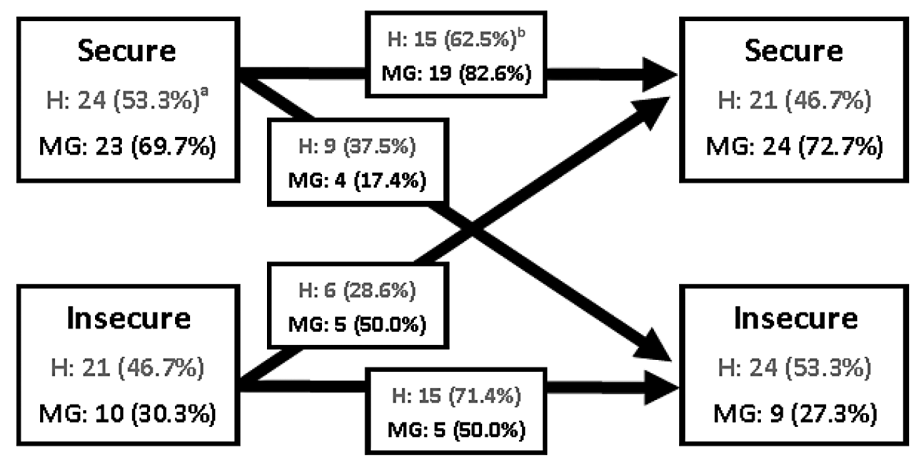

FIGURE 2. Working Model of the Child Interview ratings at baseline and postintervention for Home-based $(\mathrm{H})$ and Multifamily Group (MG) participants.

Note: $\mathrm{H}=$ Homebased, $\mathrm{MG}=$ Multifamily Group

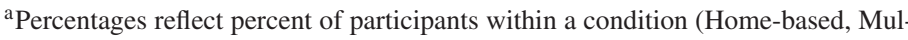
tifamily Group) and time point classified in a given category.

${ }^{b}$ Percentages reflect percent of participants within a condition and security rating (e.g., Homebased parents with a Secure rating)

postintervention WMCI ratings among Multifamily Group participants, $\chi^{2}(1, n=33)=3.736, p=.05$, and a significant association among Home-based participants, $\chi^{2}(1, n=45)=$ $5.18, p=.02$. The overall chi-squared test (Condition $\times$ Baseline WMCI $\times$ Postintervention WMCI) also was significant, $\chi^{2}(1, n$ $=78)=10.40, p<.01$. As shown in Figure 2, Secure parents were more likely to remain in the Secure category regardless of intervention condition, but this tendency was more pronounced for Multifamily Group participants (82.6\%) than for Home-based participants $(62.5 \%)$. Insecure parents were more likely to remain in the Insecure category regardless of intervention condition, but this tendency was more pronounced for Home-based participants (71.4\%) than for Multifamily Group participants (50.0\%). Furthermore, among participants who were classified as Insecure at baseline, Multifamily Group participants were nearly twice as likely to shift to Secure at postintervention (50\%) relative to Home-based participants $(28.6 \%)$, and among participants who were Secure at baseline, Multifamily Group participants were about half as likely to shift to Insecure at postintervention (17.4\%) relative to Homebased participants (37.5\%).

\section{DISCUSSION}

The current study had three main findings. First, neither parenting reflectivity nor WMCI ratings differed between mothers and fathers in military families, or between service members and civilian parenting partners. To our knowledge, no other published reports have examined these questions regarding military parents of young children. Our results suggest that all parents in military families are likely to benefit from parenting interventions, as they do not significantly differ in parenting reflectivity or WMCI ratings. Our findings regarding the similarity in parenting reflectivity in mothers versus fathers in military families stands in contrast to another 
recent study on civilian families that found fathers to perform lower on reflective functioning (Esbjørn et al., 2013). Further research is needed to examine gender differences in this area of research for both civilian and military families.

Second, regardless of intervention group, there was substantial stability in parenting reflectivity and WMCI ratings from baseline to posttest, with approximately $70 \%$ of the sample attaining the same categorization at both time points. This finding is consistent with previous research among nonmilitary populations suggesting that 71 to $76 \%$ of WMCI ratings are stable over the course of 1 year (Borghini et al., 2006; Theran et al., 2005).

Third, participation in the Multifamily Group was associated with improvements in both parenting reflectivity and WMCI ratings from baseline to postintervention. Participants in the Multifamily Group were more likely to maintain more secure and more reflective ratings from pre- to postintervention, were more likely to have improvements in their ratings, and less likely to have declines in their ratings than were Home-based participants. This is notable given that there is strong tendency for stability in reflective functioning over time (Borghini et al., 2006; Theran et al., 2005), and the control condition consisted of intervention via written materials that were mailed to parents. It is possible that discussions in the Multifamily Group about children's attachment-related behaviors, particularly discussing their own experience of these behaviors, helped Multifamily Group participants to conceptualize their children's behavior in more balanced and sensitive ways, which would contribute to maintenance of higher reflectivity ratings and improvement from lower to higher ratings. While the Home-based group received parallel psychoeducational materials, parents likely did not discuss the relevance of the ideas to their own children to the same extent as did those in the Multifamily Group; in turn, their conceptualizations of their children would be less likely to improve.

This is the first study of the effect of a group-based parenting intervention on parenting reflectivity in military families of young children. Previous work has demonstrated that Mom Power, the intervention from which SMF was derived, has significant efficacy for strengthening mothers' reflective functioning. A randomized controlled trial of Mom Power found that rates of WMCI typologies nearly doubled from baseline to postintervention for Multifamily Group participants whereas there was virtually no change in WMCI typologies among Home-based participants (Rosenblum, Lawler, Alfafara, Miller, \& Muzik, 2017).

In both SMF and Mom Power, members of the Home-based group received written materials that conveyed the core information that was presented in the Multifamily Group. Thus, it is likely that the in-person delivery and group context of the Multifamily Group are keys to its therapeutic success. In fact, studies of military families have found that social support is key to reducing risk for PTSD, depression, and suicidality in military service members (Jakupcak et al., 2010; Pietrzak et al., 2010). Thus, in this set of high-risk families, the social support and sense of community among Multifamily Group participants, along with guided interactions with their young children during separations and reunions and personalized recommendations for other community resources and services, appear to provide additional benefit beyond the psychoeducational material that was delivered to both groups. It also is likely that discussing the psychoeducational material in a group format along with other parents makes it easier for parents to understand and apply the material to the challenges that they are having with their own children.

Military families with young children endure a high level of stress, in part due to managing separations and reunions related to deployment, and they often have little guidance about how to navigate the challenges of parenting in this context. While education related to attachment is relevant for all families of young children, it can be especially vital for military families as normative, brief separations (e.g., separating for daycare) might trigger feelings related to less normative, longer separations such as deployment. The SMF Multifamily Group intervention responds to this need by bringing together valuable psychoeducation about attachment in young children and coping skills for parents, with social connection to other military families. Importantly, the Multifamily Group connects families to community resources that may be helpful to them, providing a warm hand off that is thought to increase the chances of families following through with these referrals. Particularly for National Guard and Reserve families who do not live in proximity to a military base, this intervention can provide important connections to both peers and professionals that can continue to support them beyond the end of the intervention itself.

\section{Limitations}

This study is limited by its relatively small sample size and nonrandom assignment to groups. Future studies would benefit from larger samples that could be randomly assigned to groups, which may be more possible in locations that are proximal to military bases. Further, in the current sample, participants in the Multifamily Group and home-based conditions were not equivalent in reflective parenting or WMCI codes at baseline. Group differences in both cases favored those in the Multifamily Group condition. However, analyses examined changes from baseline to postintervention rather than absolute differences between groups and still demonstrated benefits of the Multifamily Group relative to the Home-based condition. Indeed, given that the Multifamily Group was advantaged at baseline, it is perhaps more impressive that this group showed benefit over the Home-based group over the course of the intervention.

\section{Strengths}

Despite the aforementioned limitations, this study had several key strengths. First, the SMF intervention is tailored to military families with young children. This target population is especially vulnerable because of their level of stress and separations that are inherent to deployment, and this intervention specifically responds to their needs. Further, while existing interventions for military families may include some children under 7 years of age, few existing 
military family interventions specifically target children in early childhood and address issues that are most relevant to this age group. Given the great need for social support in military families, it is notable that the SMF intervention utilizes a multifamily group format that facilitates social support among the participating families as well as connection to community resources and services. The intervention, while brief, is comprehensive in its attention to attachment relationships, parents' self-care skills, developing peer social support, and connection to community resources. The intervention's focus on attachment-related psychoeducation within the context of military families is unique and valuable because it allows parents to shift their perspective of their young children's challenging behaviors and respond to them in ways that are more responsive to their children's underlying needs. SMF also is a manualized, community-based intervention. Thus, existing community providers can be trained to deliver it effectively, and providers in multiple regions of the United States have thus far been trained.

\section{REFERENCES}

Barker, L.H., \& Berry, K.D. (2009). Developmental issues impacting military families with young children during single and multiple deployments. Military Medicine, 174(10), 1033-1040. https://doi.org/10.7205/MILMED-D-04-1108

Bender, E. (2008). APA survey documents extent of MH problems in military. Psychiatric News, 43(11).

Borghini, A., Pierrehumbert, B., Miljkovitch, R., Muller-Nix, C., ForcadaGuex, M., \& Ansermet, F. (2006). Mother's attachment representations of their premature infant at 6 and 18 months after birth. Infant Mental Health Journal, 27(5), 494-508. https:// doi.org/10.1002/imhj.20103

Bowlby, J. (1969). Attachment and loss: Attachment. New York: Basic Books.

Bretherton, I., \& Munholland, K. A. (2008). Internal working models in attachment relationships: Elaborating a central construct in attachment theory. In J. Cassidy \& P. R. Shaver (Eds.), Handbook of attachment: Theory, research, and clinical applications (pp. 102-127). New York: Guilford Press.

Chawla, N., \& Solinas-Saunders, M. (2011). Supporting military parent and child adjustment to deployments and separations with filial therapy. American Journal of Family Therapy, 39(3), 179-192. https://doi.org/10.1080/01926187.2010.531647

Chu, A.T., \& Lieberman, A.F. (2010). Clinical implications of traumatic stress from birth to age five. Annual Review of Clinical Psychology, 6(1), 469-494. https://doi.org/10.1146/ annurev.clinpsy.121208.131204

Dayton, C.J., Walsh, T.B., Muzik, M., Erwin, M.S., \& Rosenblum, K.L. (2006). Strong, safe, and secure: Negotiating early fathering and military service across the deployment cycle. Infant Mental Health Journal, 27(1), 5-25. https://doi.org/10.1002/imhj.21465

DeVoe, E. R., Paris, R., Emmert-Aronson, B., Ross, A., \& Acker, M. (2017). A randomized clinical trial of a postdeployment parenting intervention for service members and their families with very young children. Psychological Trauma: Theory, Research, Practice, and Policy, 9(Suppl 1), 25-34. https://doi.org/10.1037/tra0000196

DeVoe, E.R., Ross, A.M., \& Paris, R. (2012). Build it together and they will come: The case for community-based participatory research with military populations. Advances in Social Work, 13(1), 149165.

Esbjørn, B.H., Pedersen, S.H., Daniel, S.I.F., Hald, H.H., Holm, J.M., \& Steele, H. (2013). Anxiety levels in clinically referred children and their parents: Examining the unique influence of self-reported attachment styles and interview-based reflective functioning in mothers and fathers. British Journal of Clinical Psychology, 52(4), 394-407. https://doi.org/10.1111/bjc.12024

Fonagy, P., Steele, M., Steele, H., Moran, G.S., \& Higgit, A.C. (1991). The capacity for undertstanding mental states: The reflective self in parent and child and its significance for attachment. Infant Mental Health Journal, 12(3), 201-218.

Forgatch, M.S., \& DeGarmo, D.S. (1999). Parenting through change: an effective prevention program for single mothers. Journal of Consulting and Clinical Psychology, 67(5), 711-24.

Gewirtz, A.H., DeGarmo, D.S., \& Zamir, O. (2016). Effects of a military parenting program on parental distress and suicidal ideation: After deployment adaptive parenting tools. Suicide and LifeThreatening Behavior, 46(April), S23-S31. https://doi.org/10.1111/ sltb. 12255

Gewirtz, A.H., DeGarmo, D.S., \& Zamir, O. (2017). After Deployment, Adaptive Parenting Tools: 1-Year Outcomes of an Evidence-Based Parenting Program for Military Families Following Deployment. Prevention Science, 1-11. https://doi.org/10.1007/s11121-017-0839-4

Gewirtz, A.H., Pinna, K.L.M., Hanson, S.K., \& Brockberg, D. (2014). Promoting parenting to support reintegrating military families: After deployment, adaptive parenting tools. Psychological Services, 11(1), 31-40. https://doi.org/10.1037/a0034134

Gorman, G.H., Eide, M., \& Hisle-Gorman, E. (2010). Wartime military deployment and increased pediatric mental and behavioral health complaints. Pediatrics, 126(6), 1058-1066. https://doi.org/10.1542/ peds.2009-2856

Gunnar, M.R., \& Quevedo, K. (2007). The neurobiology of stress and development. Annual Review of Psychology, 58, 145-173. https://doi.org/10.1146/annurev.psych.58.110405.085605

Hertsgaard, L., Gunnar, M.R., Erickson, M.F., \& Nachmias, M. (1995). Adrenocortical responses to the strange situation in infants with disorganized/disoriented attachment relationships. Child Development, 66(4), 1100-1106.

Jakupcak, M., Vannoy, S., Imel, Z., Cook, J.W., Fontana, A., Rosenheck, R., \& McFall, M. (2010). Does PTSD moderate the relationship between social support and suicide risk in Iraq and Afghanistan War Veterans seeking mental health treatment? Depression and Anxiety, 27(11), 1001-1005. https://doi.org/10.1002/da.20722

Jensen, P.S., Martin, D., \& Watanabe, H. (1996). Children's response to parental separation during Operation Desert Storm. Journal of the American Academy of Child \& Adolescent Psychiatry, 35(4), 43341. https://doi.org/10.1097/00004583-199604000-00009

Lester, P., Liang, L.J., Milburn, N., Mogil, C., Woodward, K., Nash, W. et al. (2016). Evaluation of a family-centered preventive intervention 
for military families: Parent and child longitudinal outcomes. Journal of the American Academy of Child \& Adolescent Psychiatry, 55(1), 14-24. https://doi.org/10.1016/j.jaac.2015.10.009

Lester, P., Mogil, C., Saltzman, W., Woodward, K., Nash, W., Leskin, G. et al. (2011). Families overcoming under stress: Implementing family-centered prevention for military families facing wartime deployments and combat operational stress. Military Medicine, 176(1), 19-25. https://doi.org/10.7205/MILMED-D-10-00122

Lester, P., Saltzman, W.R., Woodward, K., Glover, D., Leskin, G.A., Bursch, B. et al. (2012). Evaluation of a family-centered prevention intervention for military children and families facing wartime deployments. American Journal of Public Health, 102(Suppl. 1), 4854. https://doi.org/10.2105/AJPH.2010.300088

Leung, C.Y.Y., Miller, A.L., Lumeng, J.C., Kaciroti, N.A., \& Rosenblum, K.L. (2015). Maternal representations of their children in relation to feeding beliefs and practices among low-income mothers of young children. Appetite, 95, 176-181. https://doi.org/10.1016/ j.appet.2015.06.021

Lieberman, A.F. (2004). Traumatic stress and quality of attachment: Reality and internalization in disorders of infant mental health. Infant Mental Health Journal, 25(4), 336-351. https://doi.org/ 10.1002/imhj.20009

Lincoln, A., Swift, E., \& Shorteno-Fraser, M. (2008). Psychological adjustment and treatment of children and families with parents deployed in military combat. Journal of Clinical Psychology, 64(8), 984-992. https://doi.org/10.1002/jclp.20520

Maholmes, V. (2012). Adjustment of children and youth in military families: Toward developmental understandings. Child Development Perspectives, 6(4), 430-435. https://doi.org/10.1111/ j.1750-8606.2012.00256.x

Mansfield, A.J., Kaufman, J.S., Marshall, S.W., Gaynes, B.N., Morrissey, J.P., \& Engel, C.C. (2010). Deployment and the use of mental health services among U.S. Army wives. New England Journal of Medicine, 362(2), 101-109. https://doi.org/10.1056/NEJMoa0900177

Muzik, M., Rosenblum, K.L., Alfafara, E.A., Schuster, M.M., Miller, N.M., Waddell, R.M., \& Kohler, E.S. (2015). Mom Power: Preliminary outcomes of a group intervention to improve mental health and parenting among high-risk mothers. Archives of Women's Mental Health, 18(3), 507-521. https://doi.org/10.1007/s00737-0140490-z

Paris, R., DeVoe, E.R., Ross, A.M., \& Acker, M.L. (2010). When a parent goes to war: Effects of parental deployment on very young children and implications for intervention. American Journal of Orthopsychiatry, 80(4), 610-618. https://doi.org/10.1111/ j.1939-0025.2010.01066.x

Piehler, T.F., Ausherbauer, K., Gewirtz, A., \& Gliske, K. (2016). Improving child peer adjustment in military families through parent training: The mediational role of parental locus of control. The Journal of Early Adolescence, 1-22. https://doi.org/10.1177/0272431616678990

Pietrzak, R.H., Johnson, D.C., Goldstein, M.B., Malley, J.C., Rivers, A.J., Morgan, C.A., \& Southwick, S.M. (2010). Psychosocial buffers of traumatic stress, depressive symptoms, and psychosocial difficulties in veterans of Operations Enduring Freedom and Iraqi Freedom: The role of resilience, unit support, and postdeployment so- cial support. Journal of Affective Disorders, 120(1-3), 188-192. https://doi.org/10.1016/j.jad.2009.04.015

Richardson, L.K., Frueh, B.C., \& Acierno, R. (2010). Prevalence estimates of combat-related post-traumatic stress disorder: Critical review. Australian \& New Zealand Journal of Psychiatry, 44(1), 4-19. https://doi.org/10.3109/00048670903393597

Rosenblum, K.L., Dayton, C.J., \& McDonough, S.C. (2006). Communicating feelings: Links between mothers' representations of their infants, parenting, and infant emotional development. In O. Mayselses (Ed.), Parenting representations: Theory, research, and clinical implications (pp. 109-148). New York: Cambridge University Press.

Rosenblum, K.L., Lawler, J.M., Alfafara, E., Miller, N., Schuster, M., \& Muzik, M. (2017). Improving maternal representations in highrisk mothers: A randomized, controlled trial of the mom power parenting intervention. Child Psychiatry \& Human Development. https://doi.org/10.1007/s10578-017-0757-5

Rosenblum, K.L., McDonough, S.C., Sameroff, A.J., \& Muzik, M. (2008). Reflection in thought and action: Maternal parenting reflectivity predicts mind-mided comments and interactive behavior. Infant Mental Health Journal, 29(4), 362-376. https://doi.org/10.1002/imhj.20184

Rosenblum, K.L., Muzik, M., Waddell, R.M., Thompson, S., Rosenberg, L., Masini, G., \& Smith, K. (2015). Strong Military Families: A multifamily group approach to strengthening family resilience. Zero to Three Journal, 36(2), 8-14.

Ruscio, A.M., Weathers, F.W., King, L.A., \& King, D.W. (2002). Male war-zone veterans' perceived relationships with their children: The importance of emotional numbing. Journal of Traumatic Stress, 15(5), 351-357. https://doi.org/10.1023/A:1020125006371

Saltzman, W.R., Lester, P., Milburn, N., Woodward, K., \& Stein, J. (2016). Pathways of risk and resilience: Impact of a family resilience program on active-duty military parents. Family Process, 55(4), 633-646. https://doi.org/10.1111/famp.12238

Schachman, K., Lee, R.K., \& Lederma, R.P. (2004). Baby Boot Camp. Nursing Research, 53(2), 107-115. https://doi.org/10.1097/ 00006199-200403000-00006

Slade, A. (2005). Parental reflective functioning: An introduction. Attachment \& Human Development, 7(3), 269-281. https://doi.org/ 10.1080/14616730500245906

Stover, C.S., \& Kiselica, A. (2014). An initial examination of the association of reflective functioning to parenting of fathers. Infant Mental Health Journal, 35(5), 452-461. https://doi.org/10.1002/imhj.21459

Theran, S.A., Levendosky, A.A., Bogat, G.A., \& Huth-Bocks, A.C. (2005). Stability and change in mothers' internal representations of their infants over time. Attachment \& Human Development, 7(3), 253-268. https://doi.org/10.1080/14616730500245609

U.S. Department of Defense (2015). Demographics report: Profile of the military community. Retrieved from http://download. militaryonesource.mil/12038/MOS/Reports/2015-DemographicsReport.pdf

van IJzendoorn, M.H., Schuengel, C., \& Bakermans-Kranenburg, M.J. (1999). Disorganized attachment in early childhood: Meta-analysis of precursors, concomitants, and sequelae. Development and Psychopathology, 11(2), 225-249. 
Vreeswijk, C.M.J.M., Maas, A.J.B.M., \& van Bakel, H.J.A. (2012). Parental representations: A systematic review of the working model of the child interview. Infant Mental Health Journal, 33(3), 314-328. https://doi.org/10.1002/imhj.20337

Walsh, T.B., Dayton, C.J., Erwin, M.S., Muzik, M., Busuito, A., \& Rosenblum, K.L. (2014). Fathering after military deployment: Parenting challenges and goals of fathers of young children. Health and Social Work, 39(1), 35-44. https://doi.org/10.1093/hsw/hlu005

Wexler, H.K., \& McGrath, E. (1991). Family member stress reactions to military involvement separation. Psychotherapy: Theory, Research, Practice, Training, 28(3), 515-519. https://doi.org/ 10.1037/0033-3204.28.3.515
Zeanah, C.H., \& Benoit, D. (1995). Clinical applications of a parent perception interview in infant mental health. Child and Adolescent Psychiatric Clinics of North America, 4, 539-554.

Zeanah, C.H., Benoit, D., Hirshberg, L., Barton, M.L., \& Regan, C. (1994). Mothers' representations of their infants are concordant with infant attachment classifications. Developmental Issues in Psychiatry and Psychology, 1, 9-18.

Zeanah, C.H., Keener, M.A., \& Anders, T.F. (1986). Adolescent mothers' prenatal fantasies and working models of their infants. Psychiatry, 49(3), 193-203. https://doi.org/10.1521/00332747.1986. 11024321 